\title{
Review "The Development of Digital Economy in Indonesia"
}

\author{
Andre Sugito / 130315141
}

5 Maret 2019

\begin{tabular}{|l|l|}
\hline Judul & The Development of Digital Economy in Indonesia \\
\hline Volume & IJMBS Vol.8, Issue 3, July - Sept 2018 \\
\hline ISSN & $2230-9519$ (Online) \\
\hline ISSN & $2231-2463$ (Print) \\
\hline Penulis & $\begin{array}{l}\text { Ahmad Zafrullah Tayibnapis, Lucia } \\
\text { E.Wuryaningsih, Radita Gora }\end{array}$ \\
\hline Halaman & $14-18$ \\
\hline
\end{tabular}

\section{ABSTRACT}

Saat ini jumlah pengguna internet di Indonesia telah melebihi 50\% dari total penduduk, dengan pengeluaran rata-rata $\mathrm{Rp} \mathrm{6,5} \mathrm{juta} \mathrm{per} \mathrm{tahun} \mathrm{untuk} \mathrm{belanja} \mathrm{online.} \mathrm{Di} \mathrm{satu} \mathrm{sisi,} \mathrm{perkembangan} \mathrm{gaya}$ hidup digital dan industri berbasis teknologi digital telah menjadi sebuah kebutuhan, namun di sisi lain, itu akan menjadi ancaman serius bagi bisnis tradisional dan konvensional sebagai akibat dari perubahan karakteristik belanja konsumen, yaitu cepat. Praktis, dan murah.

\section{INTRODUCTION}

Saat ini dunia telah memasuki era industri 4.0 yaitu perkembangan teknologi baru dan mampu mengubah seluruh aspek dari rantai dan manajemen disetiap cabang industri, termasuk industri keuangan yang biasa dikenal dengan teknologi keuangan dan perbankan digital. Singapura, Jepang, dan Inggris adalah tiga negara pusat keuangan internasional yang telah mampu membuktikan dampak signifikan teknologi keuangan terhadap pertumbuhan ekonomi dan stabilitas sistem keuangan. Selain itu, teknologi keuangan juga mampu menghadirkan pedagang yang menerima debit dan kartu kredit pembayaran murah demi membangun infrastruktur perbankan dalam upaya untuk mendorong daya beli masyarakat. 


\section{LITERATURE REVIEW}

Jumlah uang yang beredar relative mampu dikendalikan oleh Bank Indonesia melalui berbagai kebijakan moneter instrument. Namun, hal itu bertentangan dengan permintaan uang yang sepenuhnya ada ditangan konsumen dalam hal beragam kebutuhan, seperti makanan, pakaian, dan tempat tinggal. Permintaan uang dalam pandangan klasik tercermin dalam teori kuantitas uang, dan pandangan A.Marshall adalah awal dari teori permintaan uang. J.M. Keynes (1936) yang membedakan permintaan uang tunai menjadi tiga motif yaitu: motif transaksi, motif kehati-hatian, dan motif spekulatif. Sebenarnya Keynes menyadari bahwa orang menginginkan jumlah uang tunai itu adalah bentuk kekayaan terbaik.

\section{RESEARCH METHODOLOGY}

Penelitian ini termasuk kategori kualitatif karena mampu menyelidiki dan memahami fenomena ekonomi digital dari pengguna internet, pesatnya perkembangan teknologi keuangan, dan permintaan pelanggan akan instrument pembayaran dengan kartu. Penelitian ini juga menggunakan data primer dengan 100 responden dan data sekunder berasal dari berbagai sumber yang validitasnya dapat dipertanggungjawabkan. Selain itu, penelitian ini juga menggunakan interaksionisme simbolik dan model fenomenologi eksistensial untuk dapat memahami makna yang muncul dan esensi dari pengaruh digital ekonomi, terutama untuk mengembangkan UMKM agar dapat bersaing dipasar.

\section{FINDING AND DISCUSSION}

Teknologi digital telah berkembang pesat di seluruh dunia. Namun, tidak semua negara memperhatikan berbagai manfaat pengembangan dari penggunaan teknologi. Realitas ini telah terjadi sejak lama, karena internet memiliki peran besar dalam mendorong pertumbuhan ekonomi, memperluas kesempatan kerja, dan meningkatkan layanan publik E-money yang telah mengalami pertumbuhan yang cepat sejak 2008. Pemerintah bahkan mengharuskan pengguna jalan untuk melakukan pembayaran menggunakan uang elektronik / e-money, dengan menyiapkan 20 tipe uang elektronik yang berbeda, dan menyediakan lebih banyak konter dalam mengisi ulang uang elektronik, sehingga pengguna bisa mendapatkan kenyamanan. Setiap bank memiliki lebih dari satu produk keuangan digital dan mengklaim bahwa produk yang ditawarkan lebih unggul daripada produk yang serupa dari competitor. Sharing economy pun tidak bisa dihindari karena 
industri digital membuat kegiatan lebih efisien, mengingat ekonomi sharing ini adalah pasar hybrid yang memungkinkan akses ke sumber daya yang dimiliki oleh individu atau kelompok untuk dibagikan kepada orang lain. Hasil survey pada pengguna produk teknologi digital yang terdiri dari 100 responden dengan karakteristik pengguna teknologi keuangan, perbankan digital, dan online, menunjukkan kepada orang-orang itu membutuhkan produk teknologi ini karena lebih murah, praktis, cepat dan lebih efisien. Hasil survey juga menunjukkan bahwa adanya beberapa responden yang keberatan dengan penggunaan e-money atau e-toll, yang hanya digunakan ketika melewati jalan tol, karena dapat menyebabkan kemacetan di pintu masuk dan keluar jalan tol. Keberatan juga terkait untuk terjadinya penipuan ketika melakukan transaksi online, termasuk penyalahgunaan kartu ATM dan kartu kredit saat membuat pembayaran dikasir. Generasi millennial pastinya ingin layanan yang cepat, praktis, layanan murah, dan mudah terpenuhi untuk berbagai kebutuhan mereka tanpa perlu datang ke toko, bank, asuransi dan pasar modal. Sementara itu, bisnis online semakin diminati, dan memang demikian lambat laun pergeseran bisnis offline karena adanya perbedaan harga yang cukup signifikan untuk barang yang sama. Demikian pula dengan pembelian tiket pesawat dan voucher hotel dapat dilakukan dengan mudah dan cepat tanpa perlu datang ke kantor tur dan perjalanan atau maskapai / kantor hotel.

\section{MSMEs in Digital Economy Era}

Bisnis online memiliki dampak besar terutama pada pola pikir dan perilaku masyarakat karena

prosesnya sangat cepat dan mudah. Demikian pula, banyak anak muda yang tertarik untuk melakukan bisnis online karena praktis dan tidak memerlukan modal yang besar. Penggunaan online terbukti efektif dalam memacu volume penjualan dan perluasan pasar yang pada gilirannya mampu meningkatkan ekspor dan meningkatkan pertumbuhan ekonomi Indonesia.

\section{CONCLUDING REMAKRS}

Ekonomi berbasis digital akan menjadi salah satu pendorong ekonomi pertumbuhan dan pendapatan per kapita Indonesia ditengah-tengah ekonomi global yang lesu karena perang dagang dan peningkatan harga minyak dipasar internasional, termasuk dalam mewujudkan pendapatan pemerataan. Perbankan digital dan teknologi keuangan mungkin memiliki dampak negatif yang berpengaruh stabilitas keuangan ketika data dan dokumen diakses oleh pihak lain melalui jaringan 
internet bersama dengan meningkatkan jumlah data yang didistribusikan, dan hubungannya antar perangkat dalam mengakses internet mengakibatkan kerugian ekonomi.

\section{Alamat DOI : 10.31227/osf.io/326bv}

\section{REFERENCES}

[1] Chariri, Anis.,'Landasan Filsafat dan Metode Penelitian Kualitatif. Makalah. Workshop Metodologi Penelitian Kuantitatif dan Kualitatif”. Fakultas Ekonomi Universitas Diponegoro. Semarang, 2009.

[2] Jelassi, Taufik, Albrecht Endes, "Strategies for e-business: Creating Value Through Electronic and Mobile Commerce: Concepts and Cases", $2^{\text {nd }}$ edition. United States of America: Prentice Hall, 2008.

[3] Nopirin. Ekonomi Moneter, "Edisi Keempat. Cetakan Ketujuh. Yogjakarta: BPFE, 2000.

[4] Tayibnapis, A. Z., Wuryaningsih, L. E., \& Gora, R. (2018). The Development of Digital Economy in Indonesia. IJMBS International Journal of Management and Business Studies, 8(3), 14-18.

[5] Tulman, Michael M., "E-Business and E-Commerce for Managers", United States of America: Prentice Hall, 2001. 